\title{
BUILDING URBAN WATER RESILIENCE NEW PERSPECTIVES FOR THE GUADALAJARA DROUGHT-READINESS PROGRAM
}

\author{
RODRIGO FLORES-ELIZONDO \\ Department of Habitat and Urban Development \\ ITESO, Jesuit University of Guadalajara \\ Tlaquepaque, Jalisco, México \\ rflores@iteso.mx
}

\begin{abstract}
Climate change is compelling cities to become resilient in the face of a wider range of meteorological phenomena. Starting with approaches to cope with hurricanes or floods, resilient city strategies have to consider longer-term and more territorially expansive challenges, such as multiannual and multi-regional droughts. Urban planners, local and regional governments, and political consultants are therefore driven to consider more complex models to build resilient cities. One example is the case of Guadalajara, Jalisco, Mexico's second largest city and which was recently included in the 100 Resilient Cities network. The city obtained a drought management program from the federal government in 2015, but such efforts have not yet been coordinated with current public policy or with the rapid growth of the city. This article explores a more comprehensive proposal of public policy to deal with a big city's water supply and expected shortages. It combines elements from the Resilience Alliance methodology and the Transition to Urban Water Services of Tomorrow (TRUST) Program funded by the European Union.
\end{abstract}

Keywords: Guadalajara; urban water supply; resilience; governance 


\section{INTRODUCTION}

Large cities around the world face serious challenges brought on by climate change. Their growth, for example, tends to outstrip their capacity to manage basic resources like water. On top of such chronic conditions, how can they be expected to deal with acute events like droughts? Cities, therefore, must make themselves resilient, and this, in fact, is precisely what the United Nations expects and expresses through the Sustainable Development Goals of 2015.

The concept of resilience shows great promise as an approach for building paradigms that help to recognize shifting realities and human communities' responses to them. With its roots in sciences as diverse as physics, ecology, and psychology, resilience has been gaining widespread acceptance due to the possibilities it seems to offer for taking on the challenges of a world with a high level of vulnerability and growing uncertainty, one that is in constant crisis. Its greatest virtues include an openness to accepting risk and uncertainty as permanent features of the landscape. This vision, however, presents the concept of resilience as a kind of panacea for all the ills afflicting humanity, and attracts the attention of diverse segments of the population.

Like the paradigm of sustainability, resilience is understood in many different ways, depending on the attributes that certain actors wish to highlight. For example, the United Nations Office for Disaster Risk Reduction (UNISDR) defines resilience both in terms of preventing human casualties and property damage in the event of catastrophes and ensuring that affected populations recover quickly (UNISDR, 2012). Another concept of resilience focuses on modeling in an attempt to comprehend complex systems where slowly developing changes could lead to collapse if they are not properly managed (Bermejo, 2008; Bahadur, Ibrahim, \& Tanner, 2010; Resilience Alliance, 2010; Smith, Ramoa, Galvao, Monteiro, \& Jeffrey, 2015). This is the kind of resilience that the World Bank seeks to promote as a regional effort (World Bank, 2013; 2016), and yes it is also an urban-scale concern (Ramôa, Toth, Proença de Oliveira, di Frederico, Montanari, Monteiro, 2015; Smith et al., 2015).

This article discusses the first results of a research project in progress called Building Urban Water Resilience. It seeks to deal with the urban water shortage in the Guadalajara Metropolitan Area (GMA). According to government data, this city in Western Mexico with close to five million inhabitants is reaching the limits of its water supply. There 
are no reserves to face growing demands or to deal with a drought. In response, the federal water authority (Conagua ${ }^{1}$ ) developed a pilot drought-prevention and -mitigation program (Pronacose, 2015) and presented it to the local water agency $\left(\mathrm{SIAPA}^{2}\right)$. A couple of years later, the program had not yet been implemented, and still offers multiple areas for improvement in terms of resilience.

The proposed methodology for analyzing this program has two stages. First, it uses the assessment framework offered by the Resilience Alliance (2010) guide, which in turn is complemented in the second stage by a study of the European Union's TRUST series (Ramôa et al., 2015; Smith et al., 2015) ${ }^{3}$, which analyzes urban system strategies that could be reoriented toward resilience. The objective is to generate new perspectives for building urban water resilience.

\section{CONCEPTS OF RESILIENCE}

Different studies exploring the epistemology of resilience agree that the term and its usage have evolved. It originally referred to static realities, such as in $19^{\text {th }}$-century materials science, before expanding to applications in ecology (Holling, 1973; Allen, Angeler, Garmestani, Gunderson, \& Holling, 2014), psychology (Brooks \& Goldstein, 2004; Melillo, Suárez Ojeda, \& Rodríguez, 2008; Puig \& Rubio, 2011; Rubio \& Puig, 2015), socio-ecological (Adger, 2000; Landrum, Dybzinski, Smajlovic, \& Ohsowski, 2015) and socio-economic systems in general (Bermejo, 2008; Porter \& Davoudi, 2012; Shaw, 2012; Soares de Moranes, 2014), and organizational management in particular (Zolli \& Healy, 2012; Véliz Montero, 2014). The scope of the concept has also evolved: from the simple physical property of resisting an external force without breaking - the degree of flexibility (material resistance) - to the changes that a system can undertake to conserve its essential functions in the face of an external threat (ecosystem resilience). Psychological resilience is more interesting as it involves not just returning to the state prior to the disruptive event but also gaining strength in the process. In other words,

${ }^{1}$ National Water Commission; "Conagua" in Spanish.

${ }^{2}$ The Inter-municipal System for Drinking Water and Sewer Services (SIAPA in Spanish) was founded in 1978 and serves roughly $90 \%$ of the population of the GMA. The half-a-million inhabitants who are not included live in the outlying municipalities and draw their water entirely from wells.

${ }^{3}$ This study was undertaken as part of the series Transitions to the Urban Water Services of Tomorrow (TRUST), financed by the European Union Seventh Framework Programme. 
it offers the possibility that individuals will emerge from the challenge positively transformed and somehow improved. What, then, might this improvement consist of at the community level (Zolli \& Healy, 2012; Uriarte, 2013)? What is needed to achieve it?

The relevant literature available has reached a certain consensus about the attributes that contribute to social resilience. They range from the community-wide provision of necessary and desirable conditions for individuals such as cultural identity, community self-esteem, and social humor and trust between the community and the government (Uriarte, 2013) to an understanding of what elements are seen as fundamental for building this resilience. A study of 16 contemporary authors led Bahadur and colleagues to identify the following ten elements (Bahadur et al., 2010):

- a high level of diversity;

- effective governance;

- perception and acceptance of uncertainty and change;

- community involvement and the inclusion of local knowledge;

- preparedness, planning, and readiness;

- a high level of equity;

- adequate social values and structures;

- non-equilibrium system dynamics;

- learning; and

- cross-scalar perspective.

It is also important to examine different perspectives to determine the agency that drives the construction of resilience in each case. Some of the texts reviewed use terms such as "stakeholders" or "interest groups." The term "agency," which refers to the ability to effect meaningful changes outside one's own sphere of influence (Giddens, 1995), works better inasmuch as it assigns an active role to the subject or group. For example, UNISDR, on the one hand, emphasizes the government's role in limiting deaths and suffering among the general population, in restoring essential infrastructure (communications, energy, water, and other services), and in channeling investment so that development matches the region's particular needs (UNISDR, 2012). At the other end of the agency spectrum, on the other hand, is the study of strategies by which communities adapt to changes (Uriarte, 2013; Soares de Moranes, 2014). In this community-based construction of resilience, certain social structures coalesce over time: social capital; trust as well as information from and dialogue with authorities; a history of positive responses to disruptive events; and participation, collective effort, involvement, and 
experiences of self-organization (Uriarte, 2013). If resilience can thus be understood as the recovery of society's functions and metabolisms, the discussion can also focus on recovering the means that sustain everyday life, i.e., the components of relationships, capacities, and assets or resources that different individuals use to cope with and recover from stress and crisis. These components also provide the next generation with sustainable opportunities for subsistence and assure net benefits from other means of local subsistence in the short and medium term. For this purpose, Soares de Moranes (2014) identifies six types of capital:

- Social Capital: formal and informal relations among members (exchange of benefits)

- Human Capital: skills, knowledge, health, education

- Political Capital: decision-making mechanisms and their institutions

- Natural Capital: natural resources available to the community (direct environmental services)

- Financial Capital: cash and liquid assets (salable livestock), transfers, pensions

- Physical or Built Capital: basic infrastructure (housing, services) and physical assets

The building of community resilience would thus be oriented toward reinforcing the kinds of capital that are most vulnerable and volatile in a catastrophic event. In one study, Soares de Moranes (2014) looks at four hurricane-prone communities in Yucatán to find out how these different types of capital can compensate for one another. It is obvious that the meteorological event affects natural, built, and financial capitals. At the community level, the reinforcement of the other three kinds of capital can eventually compensate to a certain extent for the losses and shorten recovery time. Nevertheless, as Uriarte (2013) pointed out, preexisting fragility such as poverty and mistrust of government, among other factors, can aggravate the problems and even degenerate into new problems such as domestic violence (heads of household who do not recover their economic activity or financial liquidity often report depression and frustration) and prostitution.

Socio-economic resilience is an approach that helps to generate more effective preparations for the challenges of uncertainty, but what can be done to come up with more complex strategies that include responses not only to catastrophic and relatively short-lived events (such as hurricanes or droughts) but also to man-made vulnerabilities (such as overdrafts on a city's water reserves even when there is no drought, or aging infrastructure without any plan to replace it)? 


\section{BUILDING URBAN WATER RESILIENCE}

Among the Sustainable Development Goals (SDG) adopted recently by the United Nations, numbers 6 and 11 are important for the purposes of this article: Ensure availability and sustainable management of water and sanitation for all, and Make cities and human settlements inclusive, safe, resilient and sustainable. Specific targets 11.5 and 11.b warrant special attention:

11.5 By 2030 significantly reduce the number of deaths and the number of affected people and decrease by $\mathrm{y} \%$ the economic losses relative to GDP caused by disasters, including water-related disasters, with the focus on protecting the poor and people in vulnerable situations.

11.b By 2020, increase by $\mathrm{x} \%$ the number of cities and human settlements adopting and implementing integrated policies and plans towards inclusion, resource efficiency, mitigation and adaptation to climate change, resilience to disasters, and develop and implement, in line with the forthcoming Hyogo Framework, holistic disaster risk management at all levels. (ICSU, ISSC, 2015:3)

Scientific experts assessed the complete list of SDG targets and proposed that most of the formulations (these two included) "could be strengthened by being more specific" (ICSU, ISSC, 2015: 1). Even in this ongoing debate, the objective of nations is clear: to develop safe and resilient cities. The challenge is that these cities and their water management have not been resilient or sustainable at all in the last century. In Mexico, for instance, policies aimed at meeting water demand primarily for irrigation and urban consumption during the $20^{\text {th }}$ century led to the construction of a series of infrastructure projects (Conagua, 2011). This development affected the natural water cycle and the ecosystem services that it supported (MEA, 2005). Only in recent years has Mexican society begun to look for alternatives that might relieve the stress put on the environment, such as including treated wastewater in the supply.

There is no strategy, however, for building urban water resilience to prepare the country for events such as the droughts expected due to climate change. The public policy that comes closest is the National Drought Prevention Program ("Pronacose" in Spanish) launched in 2013. In 2014, the National Water Commission ("Conagua" in Spanish, and the federal authority responsible for the program) developed a pilot program of actions for Guadalajara, Jalisco, the country's second 
largest city (Pronacose, 2015). The said program, however, focuses only on monitoring hydro-meteorological conditions to determine when a severe level of drought is being reached and when to declare a series of measures restricting water use among different social actors (businesses, governments, and the population at large). The board of the local urban water agency (SIAPA) has the complicated task of implementing and enforcing the system, but without separate infrastructure for the business and domestic sectors, the board's only tool for controlling consumption during a drought is the pricing mechanism. The situation also gets more complicated when the businesses that use the most water in their processes have their own wells with permits granted by the federal government and not by the local water board. Thus, while the prioritization of uses respects the human right of access to water (household uses first, then public uses, and finally commercial and industrial consumption), it is easy to foresee that the poor inhabitants of the city will be the ones to shoulder the heaviest burdens of the drought. It is possible to conclude, therefore, that the Pronacose is only a contingency plan and not an urban resilience program.

What contributions could a well-planned alternative resiliencebuilding approach make so that the disruptive event not only never escalates into catastrophe but actually becomes an opportunity for social improvement? The GMA grew from 500,000 inhabitants in 1950 to almost 5 million at present. Without considering any other factors aside from its socioeconomic growth, this city is already jeopardizing its water supply. With sources stretched to the limit, could the resilience approach help identify and manage the slow-moving developments that threaten the quality of life of Guadalajara's most vulnerable citizens?

\section{SETTING BOUNDARIES TO THE SYSTEM}

To evaluate the resilience of a socio-ecological system, the Resilience Alliance (RA) published a workbook to guide agents through the implementation of these concepts (Resilience Alliance, 2010). The document first proposes setting boundaries to the system under evaluation and defining a focus of analysis as well as key components. In an iterative exercise, the guide proposes a series of steps to identify the variables that can modify the system and push it toward thresholds of major changes. The aim is to visualize all these elements on a single diagram, as well as their dynamics, thresholds, interconnections, and complex cycles, to come up with dynamic lines of action. The following sections describe these elements while applying the method to the GMA and its resilience to drought. 


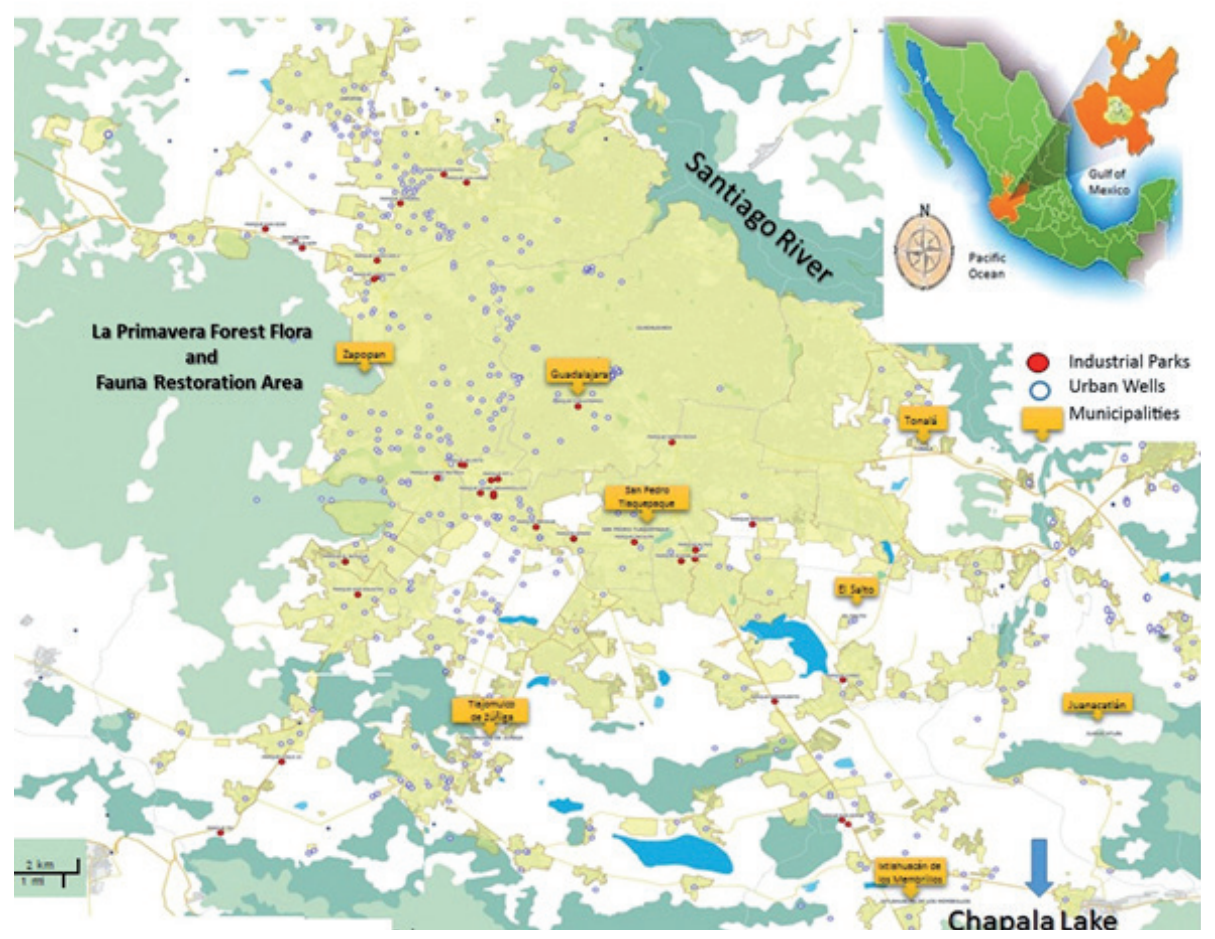

Figure 1: Guadalajara Metropolitan Area (Source: author's own formulation)

The founders of Guadalajara settled in the Atemajac Valley in Western Mexico almost five hundred years ago. The city remained small enough to meet its water needs by drawing from local rivers until the early $20^{\text {th }}$ century, when the railroad link to the Port of Manzanillo on the Pacific coast turned the city into the country's second-leading hub of economic growth, trailing only the Mexico City Valley. A burgeoning manufacturing sector produced primarily foods and beverages, machinery and equipment, textiles, furniture, chemicals and pharmaceuticals, and footwear (Woo, 2001). Systems of wells and infrastructure projects began to tap water supplies from farther and farther away, eventually sparking conflicts with other major users of the Lerma-Chapala Watershed-farmers who depended on irrigation, pig breeders, industrialists, and urban users including Mexico City (see Figure 2) - with whom a distribution agreement was reached in 1991. This agreement underwent serious strain during the drought that affected the watershed from 1997 to 2003, after which it was reviewed and renegotiated, with a new edition signed in 2004 (Flores, 2014). During this drought, Guadalajara's water supply teetered on the brink: the Lerma-Chapala Watershed Council cut its allotment by $20 \%$ and the SIAPA board temporarily imposed staggered suspensions of 
water service throughout the city. When rains replenished the supply, Guadalajara's allotment went back to previous levels, regular service was reestablished, and the city continued its growth ${ }^{4}$ and its march toward vulnerability thresholds.

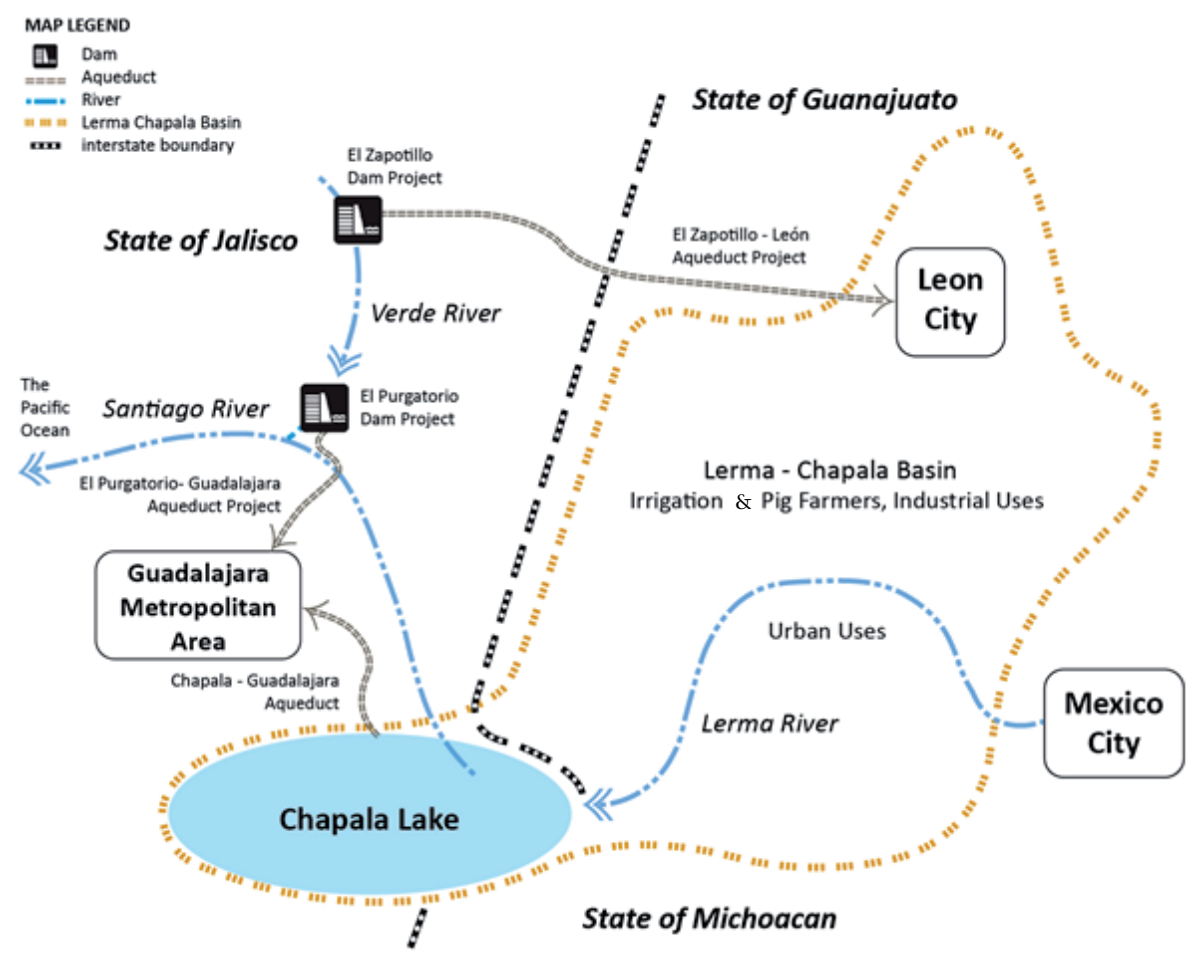

Figure 2: Outline of Guadalajara Metropolitan Area and Region: Sources and Users of Surface Water (Source: author's own formulation)

The supply for the city saw its last major investment in the 1990's, after which it totaled $280 \mathrm{Hm}^{3}$ per year: $30 \%$ from wells, $60 \%$ from Lake Chapala, and 10\% from the Calderon Reservoir. Minor adjustments have raised the supply to $300 \mathrm{Hm}^{3}$ over the last two decades. The number of users, however, has increased by over 50\%, which means that the per-capita provision has dropped to 197 liters per inhabitant per day ${ }^{5}$. To increase the water supply available to the city, the government has

${ }^{4}$ Guadalajara had an estimated 100,000 inhabitants in 1900, occupying just under 1,000 hectares. By 1970, it had grown to over a million and a half inhabitants, and almost 17,000 hectares. Its population is estimated to have passed the 4.8 million mark in 2015, spread out over almost 65,000 hectares (IMEPLAN, 2015).

${ }^{5}$ The World Health Organization recommends a per-capita provision of between 100 and 200 liters a day (WHO, 2003); Guadalajara's rate of 197 falls within this range. 
projected a new system of dams on the Verde River north of the city (see Figure 2). What is overlooked is the fact that an eventual drought will bring down the levels of reservoirs, lakes, and rivers alike, which lends urgency to the task of building urban water resilience. In terms of territory, aquifers are being neglected, but other subsystems also call for attention, primarily the socio-ecological system surrounding Guadalajara.

\begin{tabular}{|c|c|c|}
\hline $\begin{array}{l}\text { Main } \\
\text { Issues }\end{array}$ & Facts & Observations \\
\hline Municipalities involved & 9 & \multirow{2}{*}{$\begin{array}{l}\text { The } 4 \text { seats of the main municipalities } \\
\text { are included in the Guadalajara Urban } \\
\text { Area }\left(G \cup A^{6}\right) \text { : Guadalajara, Zapopan, } \\
\text { Tlaquepaque, and Tonalá (see Figure 1) }\end{array}$} \\
\hline $\begin{array}{l}\text { Millions of inhabitants in } \\
2015\end{array}$ & 4.8 & \\
\hline $\begin{array}{l}\text { Millions of inhabitants } \\
\text { served by SIAPA }\end{array}$ & 4.1 & SIAPA supplies almost all of GUA \\
\hline $\begin{array}{l}\text { Surface water supply } \\
\left(\mathrm{m}^{3} / \mathrm{s}\right)\end{array}$ & 6.5 & $\begin{array}{l}\text { Surface water system supplies only } \\
\text { SIAPA zone. No reserves available. }\end{array}$ \\
\hline Groundwater supply $\left(\mathrm{m}^{3} / \mathrm{s}\right)$ & 4.5 & Aquifers overexploited \\
\hline $\begin{array}{l}\text { Current water demand } \\
(2016)\left(\mathrm{m}^{3} / \mathrm{s}\right)\end{array}$ & 10.5 & $\begin{array}{l}\text { Peaks of demand reach total supply } \\
\text { capacity during dry season. }\end{array}$ \\
\hline $\begin{array}{l}\text { Estimated increase of } \\
\text { demand by } 2020\end{array}$ & $6 \%$ & \multirow{2}{*}{$\begin{array}{l}\text { Based on expected increase of users at } \\
\text { current consumption per user }\end{array}$} \\
\hline $\begin{array}{l}\text { Estimated increase of } \\
\text { demand by } 2030\end{array}$ & $14 \%$ & \\
\hline $\begin{array}{l}\text { Main municipal } \\
\text { sanitation plants }\end{array}$ & 2 & $\begin{array}{l}\text { Combined capacity of } 10.75 \mathrm{~m}^{3} / \mathrm{s} \text {. } \\
\text { Marginal reuse of treated wastewater. }\end{array}$ \\
\hline $\begin{array}{l}\text { Water Supply Projects } \\
\quad \text { (see Figure 2) }\end{array}$ & $\begin{array}{l}\text { Additional } \\
\text { Supply } \\
\text { Expected }\end{array}$ & Reasons for Delay \\
\hline El Purgatorio Dam Project & $5.6 \mathrm{~m}^{3} / \mathrm{s}$ & Held up by federal budget reductions \\
\hline El Zapotillo Dam Project & $3 \mathrm{~m}^{3} / \mathrm{s}$ & Stopped by federal legal process \\
\hline $\begin{array}{l}\text { Second Chapala } \\
\text { Aqueduct }\end{array}$ & $2 \mathrm{~m}^{3} / \mathrm{s}$ & Stopped for local political reasons \\
\hline
\end{tabular}

Table 1. Guadalajara Metropolitan Area Hydrological System (Source: Ochoa \& Bürkner [2012]; SIAPA [2016]; and Jalisco State Water Commission's page: www. ceajalisco.gob.mx)

However, it is important to point out that $30 \%$ of this supply is lost to physical inefficiency. Moreover, the ongoing urban growth has the system's planners worried. 
The RA methodological guide calls for delimiting a main socioecological system; for our exercise, this main system is the GMA (comprising nine municipalities [see Table 1]), with the focal subsystem being the hydrological region from which the water supply is extracted (see Figure 2). The next step is to define the risk that necessitates an increase in resilience: in this case, water shortages due to drought and depletion of the city's water supply. As a complete socio-ecological system, the GMA has developed socio-economically but it has also transformed the surrounding landscape: large farming operations and small farming villages have given way to urban centers, industrial parks, and a variety of services (see Figure 1). Wells that used to water crops and livestock now provide for urban users. The process has been disorderly, with little oversight-six of the GMA's seven aquifers are now overexploited, with the remaining aquifer located within the protected natural area known as La Primavera Forest ${ }^{6}$ bordering the city on the west. Lake Chapala, for its part, is located 40 kilometers southeast of Guadalajara (see Figure 1) and has a reserve of almost $8000 \mathrm{Hm}^{3}$, making the $240 \mathrm{Hm}^{3}$ allotted annually to the city inconsequential in times of abundance. During the drought mentioned earlier, however, the lake's level dropped to below $25 \%$ of its capacity, and the city's water withdrawals clashed with the needs of agricultural users along the Lerma River because authorities forced them to give up significant portions of their allotments to transfer them to Lake Chapala. As such, while the 2004 distribution agreement takes a more preventive tack than the 1991 version, in the final analysis it provides no definitive solution to conflicts like the one that arose between Guadalajara and the farming interests of the neighboring state of Guanajuato, conflicts which could trigger a veritable water war in Western Mexico. ${ }^{7}$ Figure 3 shows these elements.

${ }^{6}$ The La Primavera Forest Flora and Fauna Restoration Area was created by presidential decree in 1982.

${ }^{7}$ Showing little political skill, the governors of the adjacent states of Jalisco and Guanajuato allowed tensions to rise over water allotments from the Lerma River: Guanajuato has major irrigation districts, while Jalisco supplies water downstream, primarily from Lake Chapala, to its capital city of Guadalajara. Tensions reached such a pitch that preventive federal police had to be deployed at strategic points along the Lerma River to safeguard the water transfers that had been agreed to in the LermaChapala Watershed Council. The offices of the Presidency of the Republic, plus timely rainfall, helped to calm the political waters, and the 2004 distribution agreement was successfully negotiated (Flores, 2014). 


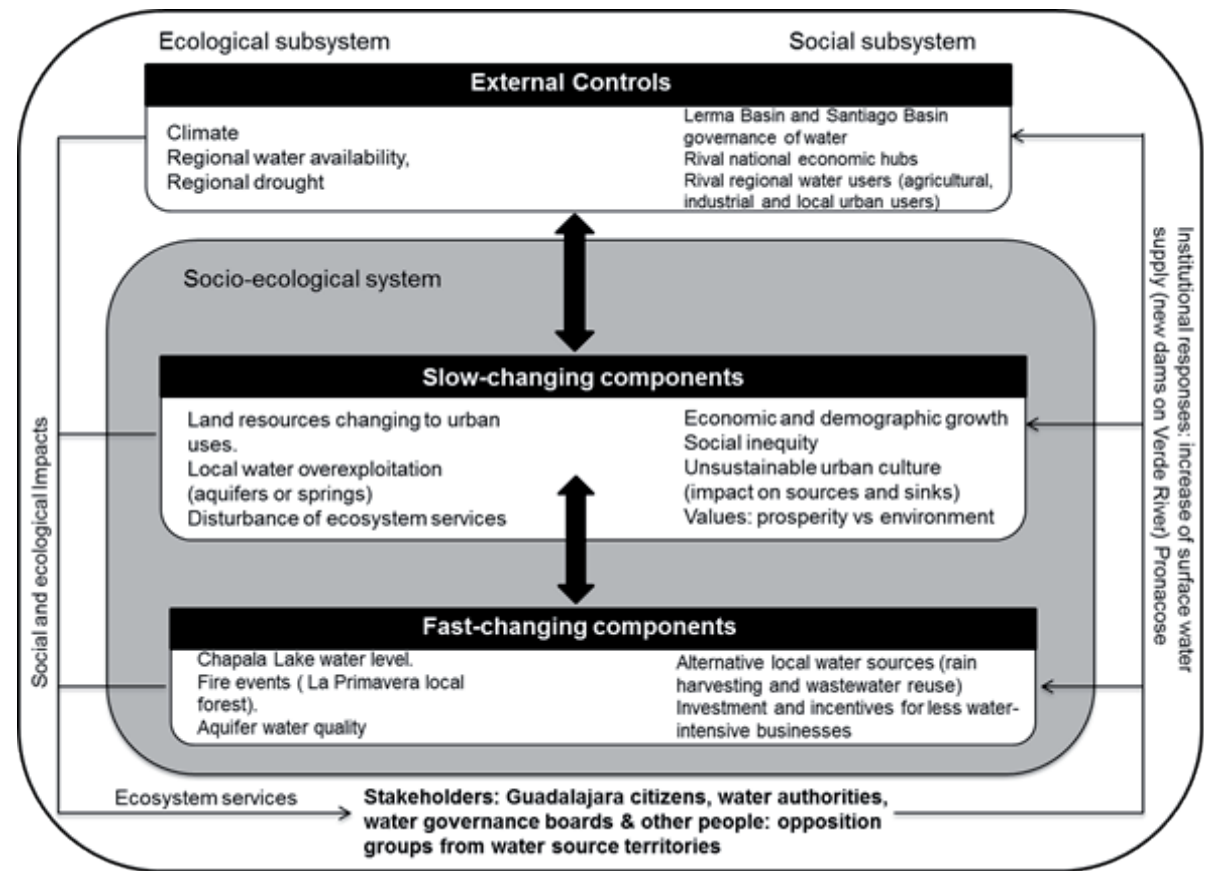

Figure 3: Conceptual model of the Guadalajara socio-ecological system and its components in the face of droughts (Source: Author's own adaptation based on Resilience Alliance, 2010)

The external elements that affect the system can be divided into ecological factors (climate, regional availability of water, and regional droughts) and social factors (competition for water within the LermaChapala supply basin, water governance assemblies such as the Watershed Councils, and factors that affect the city's prosperity such as rival economic hubs).

Within the system being analyzed (the GMA), a distinction can be made between ecological factors contributing to slow-moving change (changes in land use, availability of local water, and the ecosystem services left intact in the city) and social factors contributing to such change (population growth, social inequity, unsustainable culture, and prosperity-centered values that trump environmental values). Components of fast-moving change include water supply (water levels in Lake Chapala and local aquifers) and fires in the Primavera Forest due to their effect on temperatures in the city. Fast-moving social factors could be alternative water markets, investment, and economic incentives for businesses to use water more sparingly (see Figure 3). All these modify the system's impact on the ecosystem services that underlie the city's prosperity. 
For local authorities, it is clear that the whole socio-ecological system is supported by the hydrological system in question. As Table 1 shows, the GMA's water supply is reaching its limits while both the city and water demand are expected to grow considerably in the coming years. The institutional response in recent times has been to increase the supply of water from projected dams on the Verde River and to ration the public provision of water as set forth in Pronacose (2015). This article up until now has established these strategies as too complicated and unable to assure the water supply for the city in a climate change scenario (the bottom of Table 1 recaps the critical delays of new water projects for the GMA). A resiliency-based approach could thus open up new possibilities based on governance.

\section{ADAPTIVE CYCLES AND PANARCHY}

The diagram in Figure 3 can help lay out the elements and the relations among them in a resilience analysis, but it is also important to establish how the dynamic system works. For this purpose, Holling cycles and panarchy concepts are useful as long as they make it possible to review and reconsider systems in permanent and complex movement and reconfiguration. Socio-ecological systems exhibit cycles that the ecologist Holling classifies into four phases: exploration and growth $(\tau)$, conservation $(\mathrm{K})$, release of capital $(\Omega)$, and reorganization $(\alpha)$ (Gunderson \& Holling, 2002; Resilience Alliance, 2010).

As Figure 4 indicates, the growth phase $\tau$ connects resources and accumulates useful capital for the system until it reaches a certain level of stability in phase K. At this point, the system deals with the conservation of the accumulated capital and connected resources. These accumulations lead to a saturation of the system that diminishes its resilience. From the $\mathrm{K}$ phase, the system could cross a threshold and become unsustainable in its complex of functions. It then begins to lose the connectedness of its resources, releasing them and losing the accumulated capital. This release phase is $\Omega$, the end of the cycle, and can be chaotic if it is not managed properly-it is understood and accepted that the end of the cycle can bring about the collapse of the system. However, this phase is not invariably chaotic; it can sometimes lead to a reorganization and a new cycle (phase $\alpha$ ). During release, resilience is also gained. However, if the capital is dispersed too much between conservation and release, there will not be enough resources for the next cycle, and a "poverty trap" ensues. 


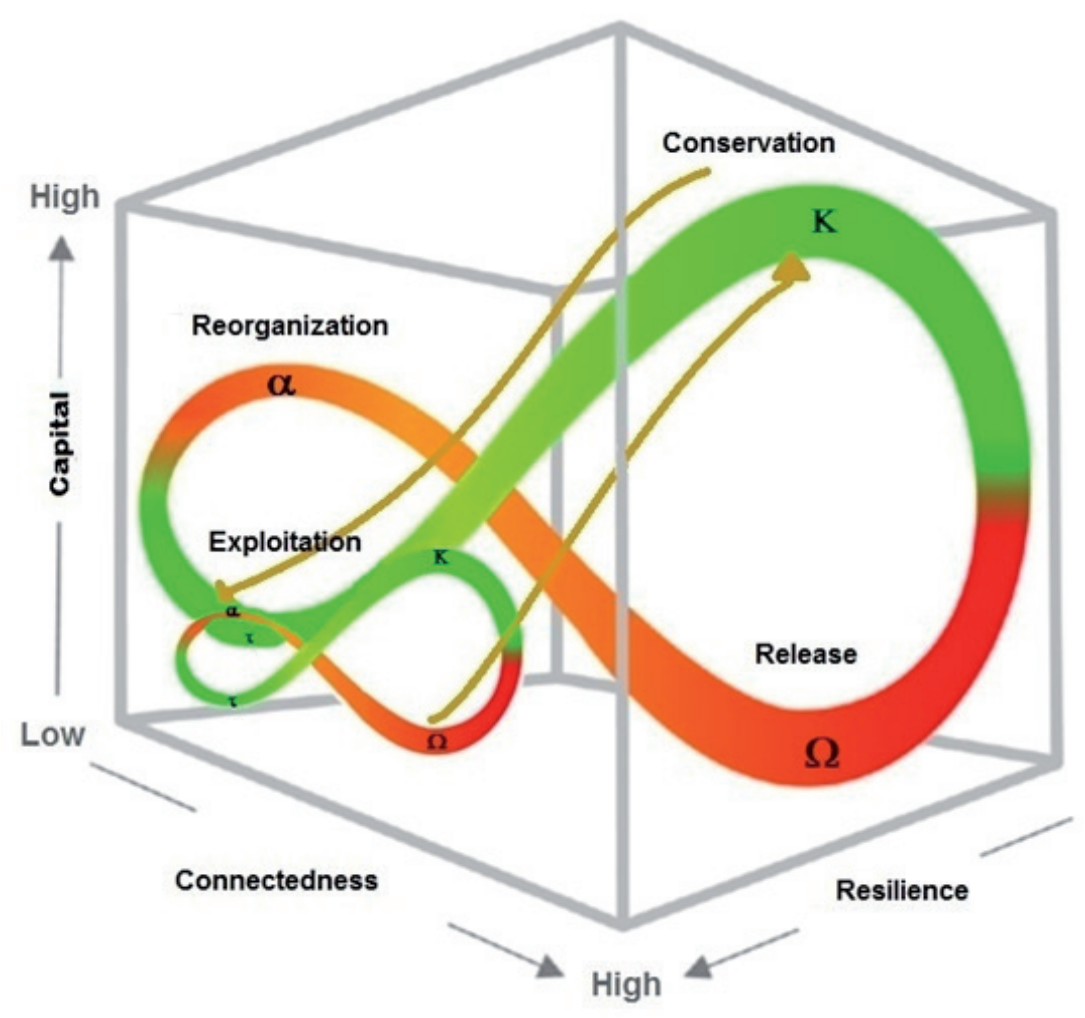

Figure 4: Holling Cycle Phases and Panarchy Illustration (Source: author's adaptation of Gunderson \& Holling, 2002; Resilience Alliance, 2010)

Systems tend to exhibit several nested cycles and can feed back from one to the other. Thus, there is a complex of cycles of different hierarchies at different moments that interact among themselves. It follows that if there is a variety of critical variables, the behavior of their cycles can come together to determine where the system is in its cycle. This model is called "panarchy" (Gunderson \& Holling, 2002; Davoudi, 2012).

Allen and colleagues (2014) propose plotting these panarchy models along at least two axes representing the time and space scales. The system whose Holling cycle is being studied is placed at the highest point of both axes, and then is gradually stripped of subsystems as the relations and moments of their own cycles affect the performance of the overarching system. Before designing these elucidating graphic representations, however, it is necessary to identify the key subsystems, their relations, and their status within the cycle. These exercises are iterative, and ideally require debate at different levels of governance and experimentation. 
Figure 5 displays the hydrological system of the city of Guadalajara, with three levels of niches. They are established following the European Union's TRUST guidelines (Smith et al., 2015) regarding key subsystems in urban water management. The TRUST study reviewed the pertinent literature and found that technical aspects dominated (supply, sewers, sanitation, and asset management), as expected. Topics of governance, however, have begun to gain prominence and relevance. Thus, Governance and Technical Issues are the critical categories for the system. The TRUST research proposes useful interdependence layouts between them (Ramôa et al., 2015) that help to reread the GMA case. Both issues deploy several variables derived from local aspects (see Tables 2 and 3). As represented in Figure 5, technical aspects take more implementing time than governance aspects and they are expected to last longer as well. Governance issues, on the other hand, are able to include territories higher than the combined water infrastructure can. Community issues are not included in TRUST considerations, however. They were represented in Figure 5 to indicate their relevance and their possible situation on the temporal and spatial scales.

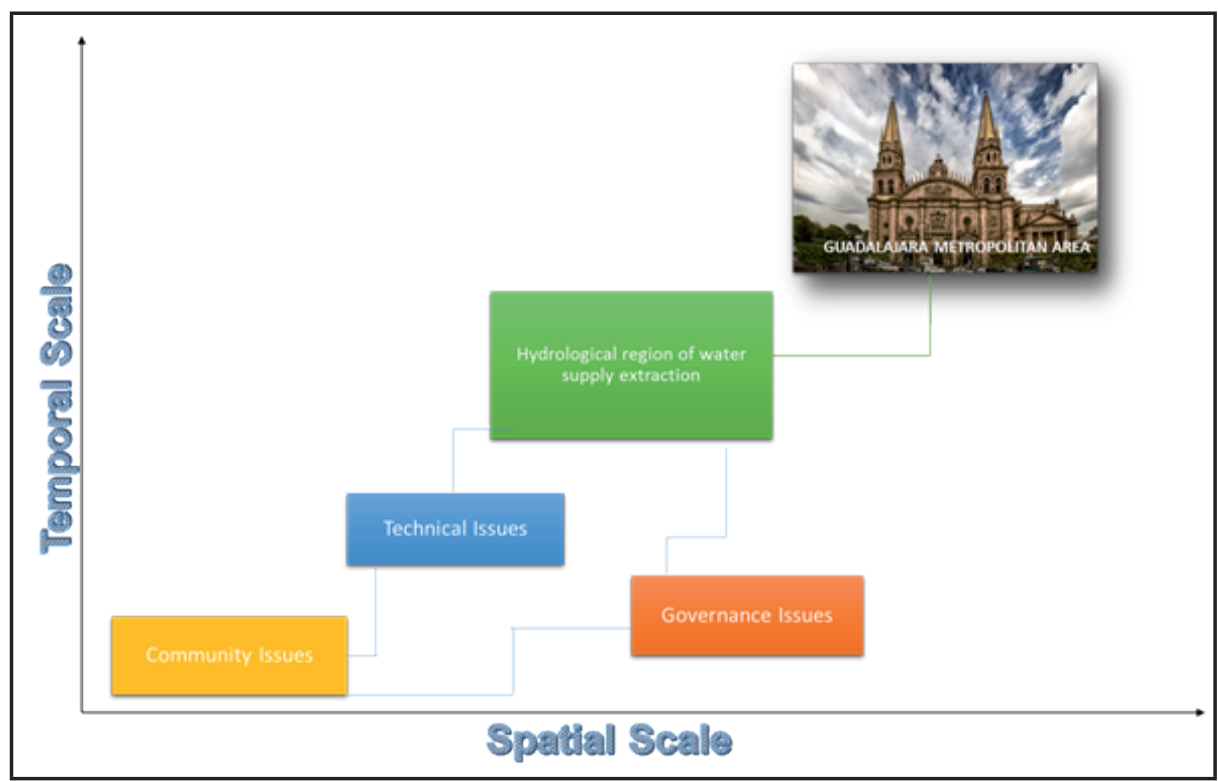

Figure 5: Panarchical outlook of some key topics for assessing the resilience of an urban water system (Source: author's own formulation based on Allen et al., 2014 and Smith et al., 2015)

To establish the critical variables of the system and their Holling cycle moments, local literature and knowledge are consulted. The concern of how to deal with water scarcity and its consequences for a growing city and its expected prosperity have led Guadalajara's social sectors 
to discuss the options for dealing with the water problem. Current water management information has recently been made available and governance assemblies have been created to address specific topics such as the water tariff and the social conflicts derived from water issues. Following TRUST's urban services draft, Tables 2 and 3 display local aspects and results, with the proposed variables being the most pertinent ones in the resilience framework under discussion.

Governance issues include water policies and regulations, financial mechanisms, and organization and management. Mexican water regulations have been evolving recently ever since the human right to water was enshrined in the Mexican Constitution in 2012. There is also a new concern with anticipating droughts by means of a federal program that combines international climate monitoring with local management plans (Pronacose, 2015). Governance assemblies have also been created or reformatted (Water Basin Councils were created twentyfive years ago) to respond to these policies, and they have clashed with the classic authoritarian style of water management which is also tending slowly toward reform. Governance issues are therefore in transition and mix classic water policies, like increasing water supply to cover projected demand, ${ }^{8}$ with new ones like the process of devising a selfsufficient tariff system with benefits for vulnerable groups and a dynamic response to drought periods. The variables deployed for this group of issues are complex and range from regulations to the agents involved in governance, as well as key actions.

\begin{tabular}{|l|l|l|l|}
\hline \multicolumn{4}{|c|}{ Issue: Policy and Regulation } \\
\hline \multicolumn{1}{|c|}{ Local aspect } & \multicolumn{1}{|c|}{ Variables } & \multicolumn{1}{c|}{ Status } & \multicolumn{1}{c|}{ Goal } \\
\hline $\begin{array}{l}\text { Increasing } \\
\text { supply of water }\end{array}$ & $\begin{array}{l}\text { Projected supply (Ps) } \\
\text { Projected demand (Pd) }\end{array}$ & Ps<Pd by 2020 & Ps>(0.8)Pd \\
\hline $\begin{array}{l}\text { Hierarchy of } \\
\text { use }\end{array}$ & $\begin{array}{l}\text { Regulated levels for } \\
\text { users }\end{array}$ & $\begin{array}{l}15 \text { regulated user } \\
\text { levels in Water Law }\end{array}$ & $\begin{array}{l}\text { Total } \\
\text { empowerment } \\
\text { of governance } \\
\text { agents }\end{array}$ \\
\hline $\begin{array}{l}\text { Implementation } \\
\text { of human right } \\
\text { to water }\end{array}$ & $\begin{array}{l}\text { Modernized legislation } \\
\text { and agents } \\
\text { empowerment }\end{array}$ & $\begin{array}{l}\text { Inclusion in National } \\
\text { Constitution (2012) }\end{array}$ & $\begin{array}{l}\text { National Water } \\
\text { Law }\end{array}$ \\
\hline
\end{tabular}

${ }^{8}$ Table 1 indicates an expected $6 \%$ growth in demand by 2020 , but previous sections of this paper make it clear that this supply policy is heading toward a crisis-it could be said that it is approaching the threshold between phases $\mathrm{K}$ and $\Omega$ in a Holling cycle. 


\begin{tabular}{|c|c|c|c|}
\hline Drought policy & $\begin{array}{l}\text { Program } \\
\text { Actions }\end{array}$ & $\begin{array}{l}\text { Pronacose, } 2015 \\
\text { Climate monitoring }\end{array}$ & $\begin{array}{l}\begin{array}{l}\text { Resilience } \\
\text { Program }\end{array} \\
\begin{array}{l}\text { Detailed plans } \\
\text { for user }\end{array} \\
\begin{array}{l}\text { Developed } \\
\text { alternative water } \\
\text { supply }\end{array}\end{array}$ \\
\hline \multicolumn{4}{|c|}{ Issue: Financial mechanisms } \\
\hline Local aspect & Variables & Status & Goal \\
\hline $\begin{array}{l}\text { Self-sufficient } \\
\text { tariff system }\end{array}$ & $\begin{array}{l}\text { Tariff }(\mathrm{T}) ; \text { Cost of } \\
\text { production }(\mathrm{C})\end{array}$ & $\mathrm{T}=(.75) \mathrm{C}$ & $\mathrm{T}>=1.1 \mathrm{C}$ \\
\hline $\begin{array}{l}\text { Benefits for } \\
\text { vulnerable } \\
\text { groups }\end{array}$ & $\begin{array}{l}\text { Low-income group } \\
\text { (LigT) and Retirement } \\
\text { (RT) tariff as percent- } \\
\text { age of regular domestic } \\
\text { users' rate. }\end{array}$ & $\begin{array}{l}\text { LigT: } 0.15 \% \\
\text { RT: } 13 \%\end{array}$ & $\begin{array}{l}\text { LigT: } 3 \% \\
\text { RT: } 10 \%\end{array}$ \\
\hline Drought tariff & $\begin{array}{l}\text { Dynamic tariff for } \\
\text { drought periods (DT) }\end{array}$ & None & $\begin{array}{l}\text { DT validated in } \\
\text { governance }\end{array}$ \\
\hline \multicolumn{4}{|c|}{ Issue: Organization and Management } \\
\hline Local aspect & Variables & Status & Goal \\
\hline $\begin{array}{l}\text { Relationships } \\
\text { between } \\
\text { government } \\
\text { levels. Year of } \\
\text { last reform }\end{array}$ & $\begin{array}{l}\text { Modernized regulation } \\
\text { of government levels } \\
\text { and agents to respond } \\
\text { to Human Right to } \\
\text { Water }\end{array}$ & $\begin{array}{l}\text { National Water Law, } \\
1992 \\
\text { Jalisco's Water Law, } \\
2014 \\
\text { Siapa's Water Law, } \\
2014\end{array}$ & $\begin{array}{l}\text { All government } \\
\text { regulations } \\
\text { respect Human } \\
\text { Right to Water }\end{array}$ \\
\hline $\begin{array}{l}\text { Governance } \\
\text { assemblies, } \\
\text { year of creation } \\
\text { or reformation }\end{array}$ & $\begin{array}{l}\text { National Water Council } \\
\text { (NWC) } \\
\text { Basin Water Council } \\
\text { (BWC) } \\
\text { Jalisco Water } \\
\text { Observatory (JWO) } \\
\text { Siapa Water Tariff } \\
\text { Council (SWTC) }\end{array}$ & $\begin{array}{l}\text { NWC, } 1992 \\
\text { BWC, } 1992 \\
\text { JWO, } 2014 \\
\text { SWTC, } 2014\end{array}$ & $\begin{array}{l}\text { All governance } \\
\text { assemblies } \\
\text { respect Human } \\
\text { Right to Water } \\
(2012)\end{array}$ \\
\hline
\end{tabular}

Table 2: TRUST's Governance Issues for GMA (Source: author's own formulation based on Mexico's water legislation [www.conagua.gob.mx]; Jalisco water legislation 
[www.ceajalisco.gob.mx]; Wester, 2008; Ochoa \& Bürkner, 2012; Conagua, 2014; Pronacose, 2015; Salazar-Adams, 2016; SIAPA [2016])

With regard to financing, Guadalajara's water authority aspires to be self-sufficient, but it is still burdened with significant liabilities. In 2012, it formed a SIAPA Water Tariff Council (SWTC) with a majority of citizen members, and which has contributed to the creation of an approach for generating revenue to cover the system's operating and maintenance costs without affecting vulnerable user groups. However, the debate as to whether a special rate should be instituted for periods of drought, as Pronacose recommends, has not yet begun.

Finally, management and organization involve agencies from all three levels of government: the National Water Commission (Conagua), the State Water Commission (CEA), and SIAPA. The relations among the three agencies vary depending on the topic, and can be considered consolidated ( $\mathrm{K}$ in the Holling cycle) but need to be reformed to respond to the human right to water. On the other hand, the SWTC and the Jalisco State Water Observatory (JWO) are governance assemblies whose importance has risen as of late.

The Technical Issues categories and variables are less groundbreaking, and local authorities normally monitor and report the indicators involved. The Jalisco State Water Commission is in charge of building and managing the main hydraulic infrastructure and of being aware of the quality and quantity of water supply sources (aquifers, lakes, and rivers). At the local government level, the water agency for the four main municipalities of the GMA is SIAPA, which publishes monthly online reports (SIAPA, 2016). This agency is in charge of the drinking water supply for the city, the treatment of wastewater, its reuse when possible (regulation limits the possible uses of cleaned wastewater), and asset management. Over the last five years, wastewater treatment has increased from $3 \%$ to $67 \%$ of wastewater produced. ${ }^{9}$ Its reuse is still marginal, however: 16 liters per second (1/s) of the potential $475 \mathrm{l} / \mathrm{s}$ market estimated by SIAPA. In addition, nearly half of the eight thousand kilometers each of supply and drainage networks, are older than the recommended thirty years of service. Leaks are estimated by SIAPA to be at $10 \%$ of the total conducted amount; ${ }^{10}$ it is not critical yet but SIAPA is already testing innovative maintenance systems. ${ }^{11}$ Finally,

${ }^{9}$ Two large-scale wastewater treatment facilities started operating in 2012 and 2014 respectively, but they are not yet running at full capacity as some major sewer lines are still missing.

${ }^{10}$ Some academics estimate that the leaks are about $40 \%$ of the total supplied amount.

${ }^{11}$ The innovative technology in use is called a "sleeve"; it is like a new internal wall for the pipe that is inserted into a damaged drainage section to stop small leaks. It is faster and less expensive than the normal procedure which entails digging up damaged lines. 
the water supply capacity is reaching current limits. As the bottom of Table 1 illustrates, new supply projects are in process but this strategy is generating ever-greater social conflicts and needs to be complemented.

\begin{tabular}{|c|c|c|c|}
\hline \multicolumn{4}{|c|}{ Issue: Water supply } \\
\hline Local aspect & Variables & Status & Goal \\
\hline Regular system & Supply (S); Demand (D) (m³/s) & S:11; D:10.5 & $S>=(0.8) D$ \\
\hline $\begin{array}{l}\text { Groundwater } \\
\text { management }\end{array}$ & $\begin{array}{l}\text { Extraction - Recharge Balance } \\
\text { (B) }\left(\mathrm{Hm}^{3} / \text { year }\right)\end{array}$ & B: -80 & $\mathrm{~B}>0$ \\
\hline $\begin{array}{l}\text { Alternative } \\
\text { sources }\end{array}$ & Rain harvesting $(\mathrm{RH})\left(\mathrm{m}^{3} / \mathrm{s}\right)$ & No data & $\mathrm{RH}>=1$ \\
\hline \multicolumn{4}{|c|}{ Issue: Urban drainage } \\
\hline Local aspect & Variables & Status & Goal \\
\hline Regular system & $\begin{array}{l}\text { Storm water flow control: conflict } \\
\text { points with more than one hour } \\
\text { of retention }\end{array}$ & 106 & No data \\
\hline \multicolumn{4}{|c|}{ Issue: Wastewater treatment } \\
\hline Local aspect & Variables & Status & Goal \\
\hline $\begin{array}{l}\text { Municipal } \\
\text { facilities }\end{array}$ & $\begin{array}{c}\text { Percentage of wastewater } \\
\text { treated }\end{array}$ & $67 \%$ & $100 \%$ \\
\hline Reuse & $\begin{array}{l}\text { Amount of wastewater reused } \\
\qquad(1 / \mathrm{s})\end{array}$ & 16 & 475 \\
\hline \multicolumn{4}{|c|}{ Issue: Asset management } \\
\hline Local aspect & Variables & Status & Goal \\
\hline $\begin{array}{l}\text { Supply / } \\
\text { drainage } \\
\text { networks }\end{array}$ & $\begin{array}{l}\text { Percentage of the network not } \\
\text { older than } 30 \text { years }\end{array}$ & About $50 \%$ & $100 \%$ \\
\hline $\begin{array}{l}\text { Innovative } \\
\text { maintenance }\end{array}$ & $\begin{array}{l}\text { Speed of network repairs } \\
\text { (km/year) }\end{array}$ & 60 & 300 \\
\hline
\end{tabular}

Table 3: TRUST's Technical Issues for GMA (Source: author's own formulation based on SIAPA [2016] and Jalisco State Water Commission's page: www.ceajalisco.gob.mx)

Once the variables' status is established, it is possible to consider a first attempt to assign each one a moment in the Holling cycle 
(Table 4 summarizes the attempt). For the Governance Issues, the policies oriented toward responding to the human right to water are connecting elements and gaining operative capital (see Figure 4); consequently, it is feasible to assign a $\tau$ to this local aspect. Drought policy implementation efforts are at the same point, and get a $\tau$ as well. On the other hand, the traditional policy of increasing the water supply is mature but reaching the saturation point. It is conceivable that it will enter into a crisis soon, and that a restructuring will be necessary (release and reorganization of its elements in the Holling framework). Thus, it makes sense to describe it with a ' $\mathrm{K}$ ' in transition to ' $\Omega$ ' $\left(\mathrm{K}-\Omega\right.$ in Table $\left.4^{12}\right)$. The rest of the moments identified have a similar rationale. While the organizational levels of water government and the hierarchical uses of water are well established (K), the tariff system, the benefits for vulnerable groups, and the governance assemblies are in development $(\tau)$. Finally, the drought tariff is included in the Pronacose (2015) proposal but has not yet been discussed in the SWTC; it therefore merits $\alpha$.

The identification of the moments of the technical issues is easier because their variables have a clearer metric between their status and the defined goals. With the exception of storm water flow control (which is dicussed in the hydraulic engineering area), the rest of the problems are about meeting a desired relation between demand and supply, or reaching the full potential point of a certain aspect (like the $475 \mathrm{l} / \mathrm{s}$ estimated by SIAPA as the maximum size of the potential local market for treated wastewater reuse). As for storm water, filtration experts on one hand propose taking advantage of such with rain harvesting and natural filtration facilities. On the other hand, water flow control experts insist that the amount of liquid is too concentrated within a short period of time, and that the most feasible solution is to build facilities to deal with the excess water that overwhelms the regular drainage system during the rainy seasons. The debate is still underway and at the moment there is no clear goal for this local aspect (Table 3). At any rate, it is clear that the drainage system is overloaded and in danger of collapse $(\mathrm{K}-\Omega)$.

\begin{tabular}{|c|l|c|}
\hline \multicolumn{3}{|c|}{ Governance Issues } \\
\hline Issue & \multicolumn{1}{|c|}{ Local aspect } & Cycle moment \\
\hline \multirow{4}{*}{ Policy and regulation } & Implementation of human right to water & $\mathrm{t}$ \\
\cline { 2 - 3 } & Pronacose program & $\mathrm{t}$ \\
\cline { 2 - 3 } & Increasing supply of water & $\mathrm{K}-\Omega$ \\
\cline { 2 - 3 } & Hierarchy of use & $\mathrm{K}$ \\
\hline
\end{tabular}

${ }^{12}$ It is important to understand that the cycle moments are indicative expressions and not mathematical equations. 


\begin{tabular}{|c|c|c|}
\hline Issue & Local aspect & Cycle moment \\
\hline \multirow{3}{*}{$\begin{array}{c}\text { Financial } \\
\text { mechanisms }\end{array}$} & Self-sufficient tariff system & $\mathrm{t}$ \\
\hline & Benefits for vulnerable groups & $\mathrm{t}$ \\
\hline & Drought tariff & $\alpha$ \\
\hline \multirow{2}{*}{$\begin{array}{c}\text { Organization and } \\
\text { management }\end{array}$} & Relationships between government levels & K \\
\hline & Governance assemblies & $\mathrm{t}$ \\
\hline \multicolumn{3}{|c|}{ Technical Issues } \\
\hline Issue & Local aspect & Cycle moment \\
\hline \multirow{2}{*}{ Water supply } & Regular system & $\mathrm{K}-\Omega$ \\
\hline & Alternative sources & $\mathrm{t}$ \\
\hline Urban drainage & Regular system & $\mathrm{K}-\Omega$ \\
\hline \multirow{2}{*}{$\begin{array}{l}\text { Wastewater } \\
\text { treatment }\end{array}$} & Municipal facilities & $t-K$ \\
\hline & Reuse & $\alpha-t$ \\
\hline \multirow{2}{*}{ Asset management } & Supply / drainage networks & $\mathrm{K}-\Omega$ \\
\hline & Innovative maintenance & $\mathrm{t}$ \\
\hline
\end{tabular}

Table 4: Resilience and transitions in Guadalajara's water sector (TRUST) (Source: author's own formulation based on Allen et al., 2014 and Smith et al., 2015)

\section{THE NEXT STEPS}

To turn these assessments and studies into actual public policies for managing Guadalajara's urban water system in the face of its own saturation and impending drought, the next step is to submit the proposals developed in this article to consultation in different forums where academics discuss water-related topics with public authorities and political decision-makers. These arenas already exist: the Jalisco Academic Water Council, the JWO, the SWTC, and the Pronacose followup commission of the Santiago River Watershed Council (the watershed to which Guadalajara belongs). These debates about building urban water resilience will meet the more comprehensive debates of the 100 Resilient Cities Network to deal a GMA plan. The Jalisco State Government's resilience workshops are proposed for 2017.

The discussion will have to touch not only on the elements of Figures 2 and 3 and the assessment of their current status within the cycles (Tables 1 to 4), but also their hierarchical relations in time and space. The expectation is that these debates will lead to the conception of new combinations of elements and new water management models at different levels. Another desirable outcome would be better informed 
social agents who take a more active role in what up to now has been the exclusive domain of a highly-specialized and closed water bureaucracy.

There is a lack of sound research about community-level resilience in the GMA. A local study (Bürkner \& Zehner, 2012) and a national survey (Ramírez-Fuentes \& Soto-Montes de Oca, 2012) suggest some community strategies to deal with water shortages, but it is necessary to generate a more complete catalog of practices to deal decisively with urban droughts.

In the end, the aim is to develop effective water management at different levels, assuring the human right to water in the city and in its surrounding region, even in times of drought.

\section{CONCLUSIONS}

After this first exercise in evaluating the Guadalajara Metropolitan Area's resilience in the face of droughts, the following conclusions can be drawn concerning its theoretical-methodological basis and its usefulness for formulating public policies.

Regarding the concept of resilience, it is clear that the discussion is ongoing. Contributions such as those of Bahadur and colleagues (2010) continue to report wide diversity when they attempt to summarize trends and identify common elements. While certain elements do stand out clearly, Bahadur reports that the statistics are scattershot when it comes to the centrality that these elements should assume within a given model and the use that should be made of them. Furthermore, it is not clear with some concepts (such as equity and democratic governance) whether they are inputs for good resilience or desired outcomes of resilience. This is what makes the visualizations proposed by projects like TRUST (Smith et al., 2015) so valuable. While governance in these proposals is still very much centered on government and its collaboration with the governed, at least a discussion is opened about topics other than technical specifications.

As for the Resilience Alliance's model (2010), it should first be pointed out that it is a handbook of concepts used to assess the resilience of a given system. It offers an operational model, although it leaves out some of the elements that other authors consider useful (Bahadur et al., 2010; Uriarte, 2013; Soares de Moranes, 2014), which means it must be complemented with other analyses. What tends to be missing is a more concrete guide about how the critical elements of the system are related 
to each other. In this case study, the complement was provided by the TRUST approach and frameworks. At the same time, however, the Alliance's model is interesting because it enables the analyst to visualize at a single glance multiple elements that are seen as having an impact on both the system as a whole and the focal theme being examined, but whose interconnections are not easily discerned. The methodological proposal offers guidelines for locating them within the whole, and even for differentiating among them. For example, it is very useful to distinguish between disruptive events that affect the system in spurts and those that exert continuous pressure (perhaps less intense than a spurt, but constant and increasing). Both can push the system to the catastrophic threshold, but they need to be managed differently.

Finally, about the system itself that was analyzed-the Guadalajara Metropolitan Area's resilience in the face of droughts and from the focal perspective of the water supply-it can be said that while no new data were obtained in this first exercise, new relationships were perceived among the data which genereated new perspectives. As far as the Drought-readiness Program (Pronacose, 2015) goes, the analysis shows that the focus needs to be regional, not local, since most of the surface water that the city uses falls as rain on, and runs off of, the lands along the Lerma River, where it is disputed by large-scale users before it even becomes available to Guadalajara in Lake Chapala. Complementary hydraulic infrastructure projects are already being built to the north of the city, but this will only duplicate the battleground of watershed councils for water allocation. ${ }^{13}$ This relationship between watersheds as water suppliers and the big growing cities requires additional exploration with a more complex approach.

At least two more issues will take on importance within the system. The first is groundwater. There is not enough information now, but it is clear that local aquifers are being severely overexploited (Peñuela-Arévalo \& Carrillo-Rivera, 2013). In the event of severe or prolonged drought, or subsequent events that dry up bodies of surface water and prevent their recovery, the region's aquifers will be the last resort (Pronacose, 2015; Smith et al, 2015). If they are depleted, and poorly monitored by regional authorities, they can hardly be expected to safeguard the city's quality of life.

The perspectives proposed by TRUST (Smith et al., 2015) suggest a second issue: the preparedness of the city itself. Is water being used

${ }^{13}$ The Santiago River Watershed Council will join the Lerma-Chapala Watershed Council to act as an arena for water allocations since the Santiago River (of which the Verde River is a tributary) will also be in dispute. 
as equitably and as efficiently as possible? Are authorities and citizens being prepared to deal with drought conditions in an orderly way, with respect for the human right of access to drinking water? At present, the answer is no, and so the hope is that the communication and discussion of resilience-based models will help to establish a common sense that will promote sound water-use measures.

To conclude, it is worth pointing out a couple of areas of opportunity that have not been fully addressed. The first has to do with the socioeconomic subsystem which is in constant transformation. The ideal scenario is that water-intensive businesses would not compete for the urban water supply; the question is how to motivate these businesses to use less water, or even to move, without driving up unemployment in the subsystem. The other is the opportunity to rethink how we define prosperity. Can we reformulate the currently accepted components (UN-Habitat, 2015) and shift them toward a different socio-ecological cycle that might come closer to the kind of world we want to build?

\section{REFERENCES}

Adger, W. N. 2000. Social and ecological resilience: Are they related? Progress in Human Geography, 24(3): 347-364. Available at http://phg.sagepub.com/ content/24/3/347 (accessed December 18, 2015).

Allen, C. R., Angeler, D. G., Garmestani, A. S., Gunderson, L. H., \& Holling, C. S. 2014. Panarchy: Theory and application. Nebraska Cooperative Fish \& Wildlife Research Unit-Staff Publications, Paper 127. Available at http:// digitalcommons.unl.edu/ncfwrustaff/127 (accessed December 18, 2015).

Bahadur, A. V., Ibrahim, M., \& Tanner, T. 2010. The resilience renaissance? Unpacking of resilience for tackling climate change and disasters. Strengthening Climate Resilience Discussion Paper 1. United Kingdom: Institute of Development Studies, University of Sussex.

Bermejo, R. 2008. Un futuro sin petróleo: Colapsos y transformaciones socioeconómicas. Centro de Investigación para la Paz. Madrid, España: Los Libros de la Catarata.

Brooks, R., \& Goldstein, S. 2004. El poder de la resiliencia: Cómo lograr el equilibrio, la seguridad y la fuerza interior necesarios para vivir en paz. México: Paidós.

Bürkner, R., \& Zehner, C. 2012. Tecnological recesses y raíces locales de place-making: Tres estudios de caso urbanos. En H. Ochoa \& J. Bürkner, Gobernanza y gestión del agua en el Occidente de México: La metrópoli de Guadalajara: 285-319. México: ITESO.

Conagua. 2011. Semblanza histórica del agua en México. México: Comisión Nacional del Agua, Gobierno de la República.

Conagua. 2014. Estadísticas del agua en México. México: Comisión Nacional del Agua, Gobierno de la República. 
Davoudi, S. 2012. Resilience: A bridging concept or a dead end? Planning Theory \& Practice, 13(2): 299-307.

Flores, R. 2014. Los Afluentes y los Ríos. La construcción social del Medio Ambiente en la Cuenca Lerma Chapala. México: ITESO.

Giddens, A. 1995. La constitución de la sociedad: Bases para una teoría de la estructuración. Buenos Aires, Argentina: Amorrortu.

Gunderson, L., \& Holling, C. 2002. Panarchy: Understanding transformations in human and natural systems. Washington, DC: Island Press.

Holling, C. S. 1973. Resilience and stability of ecological systems. Annual Review of Ecological Systems, 4: 1-23.

ICSU, ISSC. 2015. Open working group proposal for the Sustainable Development Goals and Targets. Paris: International Council for Science (ICSU).

IMEPLAN. 2015. Expansión Metropolitana 1970-2045. Instituto Metropolitano de Planeación. Guadalajara, México: Gobierno del Estado de Jalisco. Available at https://drive.google.com/a/imeplan.mx/file/ d/OB4KJF4s9aIZUY2k2SERSbENxYkE/view (accessed January 14, 2016).

Landrum, N. E., Dybzinski, R., Smajlovic, A., Ohsowski, B. M. 2015. Managing for resilience: Lessons from ecology. Journal of Management for Global Sustainability, 3(1): 75-99.

MEA. 2005. Millennium ecosystem assessment: Ecosystems and human well-being synthesis. Washington, DC: Island Press.

Melillo, A., Suárez Ojeda, E., \& Rodríguez, D. 2008. Resiliencia y subjetividad: Los ciclos de la vida. Buenos Aires: Paidós.

Ochoa, H., \& Bürkner, J. 2012. Gobernanza y gestión del agua en el Occidente de México: La metrópoli de Guadalajara. México: ITESO.

Peñuela-Arévalo, L. A., \& Carrillo-Rivera, J. J. 2013. Discharge areas as a useful tool for understanding recharge areas, study case: Mexico Catchment. Environmental Earth Sciences, 68(4): 999-1013.

Porter, L., \& Davoudi, S. 2012. The politics of resilience for planning: A cautionary note. Planning Theory \& Practice, 13(2): 329-333.

Pronacose. 2015. PMPS para usuarios urbanos de agua potable y saneamiento. Informe parcial. Comisión Nacional del Agua. México: Gobierno de la República. Available at http://www.pronacose.gob.mx/pronacose14/contenido/ documentos/PMPMS\%20Zona\%20metropolitana\%20Guadalajara.pdf (accessed January 14, 2016).

Puig, G., \& Rubio, J. 2011. Manual de resiliencia aplicada. España: Gedisa.

Ramírez-Fuentes, G. R., \& Soto-Montes de Oca, G. 2012. Estimación de los factores y funciones de la demanda de agua potable en el sector doméstico en México. México: CIDE / Conagua.

Ramôa, A., Toth, E., Proença de Oliveira, R., di Frederico, V., Montanari, A., \& Monteiro, A. 2015. Assessment of TRUST pilots. Guidelines for urban water strategic planning, Report 12.1a, TRUST D12.1a. European Union Seventh Framework Programme (FP7/2007 - 2013), agreement n. 265122. Available at http://www.trust-i.net/downloads/index.php?iddesc=148 (accessed November 10, 2016). 
Resilience Alliance. 2010. Assessing resilience in social-ecological systems: Workbook for practitioners. Version 2.0. Available at http://www.resalliance. org/files/ResilienceAssessmentV2_2.pdf (accessed November 10, 2016).

Rubio, J., \& Puig, G. 2015. Tutores de resiliencia: Dame un punto de apoyo y moveré MI mundo, prólogo de Boris Cyrulnik. España: Editorial Gedisa S.A.

Salazar-Adams, A. 2016. Fugas de agua y dinero: Factores político-institucionales que influyen en el desempeño de los organismos operadores del agua potable en México. México: El Colegio de Sonora.

Shaw, K. 2012. "Reframing" resilience: Challenges for planning theory and practice? Planning Theory \& Practice, 13(2): 308-312.

SIAPA. 2016. Informe de actividades y resultados, Octubre de 2016. Available at http://www.siapa.gob.mx/sites/default/files/doctrans/informe_octubre_2016_-_ completo_2.pdf (Accessed November 30, 2016).

Smith, H., Ramoa, A. R., Galvao, A., Monteiro, A. J., \& Jeffrey, P. 2015. Review on flexible UWCS and transitional pathways. TRUST D12.1b. European Union Seventh Framework Programme (FP7/2007-2013), agreement n. 265122.

Soares de Moranes, D. (2014). Vulnerabilidad frente a huracanes y comunicación de riesgos de desastres en la costa de Yucatán. XXIII Congreso Nacional de Hidráulica, Puerto Vallarta, México.

UN-Habitat. 2015. Guadalajara, metrópolis próspera: Redefinición del Área Metropolitana de Guadalajara como ciudad próspera en el marco metodológico del Índice de Prosperidad Urbana de ONU-Habitat. México: Gobierno del Estado de Jalisco / UN-Habitat. Available at http://www.onuhabitat.org/index. php?option=com_docman\&task=doc_view\&gid=1172\&tmpl=component\&for mat=raw\&Itemid=526 (accessed January 15, 2016).

UNISDR. 2012. Informe 2012: Desarrollando ciudades resilientes. The United Nation Office for Disaster Reduction Regional Office-The Americas, Panamá. Available at http://www.zaragoza.es/contenidos/medioambiente/onu/ newsletter12/899-spa-sum.pdf (accessed October 23, 2014)

Uriarte, J. 2013. La perspectiva comunitaria de la resiliencia. Psicología Política, 47: 7-18.

Véliz Montero, F. 2014. Resiliencia organizacional: El desafío de cuidar a las personas, mejorando la calidad de vida de las empresas del siglo XXI. España: Gedisa.

Wester, P. 2008. Shedding the waters: Institutional change and water control in the Lerma-Chapala Basin, Mexico. PhD dissertation. The Netherlands: Wageningen University.

WHO. 2003. Human right to water. Geneva, Switzerland: World Health Organization.

Woo, G. 2001. Jalisco y sus sectores estratégicos. México: Gobierno del Estado de Jalisco.

World Bank. 2013. Turn down the heat: Climate extremes, regional impacts, and the case for resilience. A report for the World Bank by the Potsdam Institute for Climate Impact Research and Climate Analytics. Washington, DC: World Bank. 
Available at https://openknowledge.worldbank.org/handle/10986/14000 (accessed November 10, 2016).

World Bank. 2016. High and dry: Climate change, water, and the economy. Washington, DC: World Bank. Available at https://openknowledge.worldbank. org/handle/10986/23665 (accessed November 10, 2016).

Zolli, A., \& Healy, A. 2012. Resiliencia: Por qué las cosas vuelven a su lugar. Bogotá: Carvajal Edicación. 